Article

\title{
Impacts of FDI Renewable Energy Technology Spillover on China's Energy Industry Performance
}

\author{
Weiwei Liu ${ }^{1,2, *}$, Xiandong $\mathrm{Xu}^{3}$, Zhile Yang ${ }^{3}$, Jianyu Zhao ${ }^{1}$ and Jing Xing ${ }^{1}$ \\ 1 School of Economics and Management, Harbin Engineering University, Harbin 150001, China; \\ zjy@hrbeu.edu.cn (J.Z.); xing.jing@139.com (J.X.) \\ 2 Management School, Queen's University Belfast, Belfast BT9 5EE, UK \\ 3 School of Electronics, Electrical Engineering and Computer Science, Queen's University Belfast, \\ Belfast BT9 5AH, UK; xuxiandong87@gmail.com (X.X.); zyang07@qub.ac.uk (Z.Y.) \\ * Correspondence: heulww@hrbeu.edu.cn; Tel.: +86-451-8251-9916
}

Academic Editor: Marc A. Rosen

Received: 16 July 2016; Accepted: 22 August 2016; Published: 29 August 2016

\begin{abstract}
Environmental friendly renewable energy plays an indispensable role in energy industry development. Foreign direct investment (FDI) in advanced renewable energy technology spillover is promising to improve technological capability and promote China's energy industry performance growth. In this paper, the impacts of FDI renewable energy technology spillover on China's energy industry performance are analyzed based on theoretical and empirical studies. Firstly, three hypotheses are proposed to illustrate the relationships between FDI renewable energy technology spillover and three energy industry performances including economic, environmental, and innovative performances. To verify the hypotheses, techniques including factor analysis and data envelopment analysis (DEA) are employed to quantify the FDI renewable energy technology spillover and the energy industry performance of China, respectively. Furthermore, a panel data regression model is proposed to measure the impacts of FDI renewable energy technology spillover on China's energy industry performance. Finally, energy industries of 30 different provinces in China based on the yearbook data from 2005 to 2011 are comparatively analyzed for evaluating the impacts through the empirical research. The results demonstrate that FDI renewable energy technology spillover has positive impacts on China's energy industry performance. It can also be found that the technology spillover effects are more obvious in economic and technological developed regions. Finally, four suggestions are provided to enhance energy industry performance and promote renewable energy technology spillover in China.
\end{abstract}

Keywords: foreign direct investment (FDI); renewable energy; technology spillover; China's energy industry performance; panel data regression

\section{Introduction}

Energy industry is a crucial part of the economy and has a significant strategic position in economic growth. In China, there is an additional urgent problem in terms of how to achieve performance growth for China's energy industry under the dual pressures of energy security and global warming. To solve this problem, the Chinese government has taken a series of actions including carrying out the Europe-China dialog on energy issues, proposing China's energy policy, and China's Go Global policy [1]. Due to the combined effects of these actions, foreign direct investment (FDI) is attracting more attention and has been an important measure for regional energy integration between China and Europe.

Renewable energy sources, such as wind, solar, geothermal, tide, etc., have the advantages of being carbon-neutral and non-depletable [2], which is why the utilization of renewable energy is 
considered a crucial step towards the achievement of sustainable development [3-5]. Thus, renewable energy investments have been the subject of intensive studies, and research interest has been growing over years. The recently proposed "One Belt, One Road" (i.e., "New Silk Road Economic Belt" and "21st Century Maritime Silk Road", an idea and initiative for cooperation development) strategy further promotes renewable energy industry development in China. This new strategy encourages the connectivity and cooperation among countries in terms of renewable energy. FDI in renewable energy takes an active response to this strategy. It improves technological capability and promotes the performance growth of energy industry [6-12].

This paper investigates the impacts of FDI renewable energy technology spillover (i.e., the technology spillover effect by introducing FDI in renewable energy industry) on energy industry (mainly includes coal mining and washing industry; petroleum and natural gas extraction industry; petroleum processing, coking, nucleus fuel processing industry; electric power, heat power production and supply industry; gas production and distribution industry; and the water production and distribution industry) performance in China. Three hypotheses are proposed and argue that FDI renewable energy technology spillover has positive impacts on multiple aspects of energy industry performance, including economic, environmental, and innovative performance. A regression model is therefore proposed to describe the relationship between FDI renewable energy technology spillover and energy industry performance in China with respect to economic, environmental, and innovative aspects. Numerical techniques including factor analysis and data envelopment analysis (DEA) are then employed to acquire the values of FDI renewable energy technology spillover and energy industry performance in China, respectively. Moreover, the panel data regression is utilized to evaluate the coefficient factor which is used to illustrate the impacts. Statistic data on the energy industries of 30 different provinces in China are utilized in the regression model.

The key findings of this paper could be summarized as follows: (1) a theoretical model is proposed to quantify the impacts of FDI renewable energy technology spillover on energy industry performance. It can be seen that FDI renewable energy technology spillover has positive impacts on China's energy industry performance, with the overall quantitative impacts being significant at $1 \%$ confidence level; (2) the regions more developed in economy and technology have greater factor scores of FDI technology spillover, which means that their technology spillover effects are more obvious. For successful economic planning, the proposed model provides a useful tool and complementary experiences for policymakers in making reasonable decisions for FDI technology spillover in different areas of China.

The remainder of the paper is organized as follows. Section 2 provides an overview of previous studies on FDI technology spillover and energy industry performance, followed by Section 3 in which the study hypotheses and theoretical models are proposed. Section 4 introduces the methodology and data. Section 5 presents the numerical results and discussions. Section 6 concludes with the major findings from the methods and their policy implications.

\section{Literature Review}

\subsection{FDI Technology Spillover}

Previous studies on FDI technology spillover have largely focused on its impact on economic growth and total factor productivity. Seck [13], Ouyang and Fu [14] and Bai et al. [15] found that technology spillover is proportional to the regional economic growth. As a critical factor of national economy, the FDI technology spillover in the energy industry has been studied in the literatures. Lin et al. [16] investigated price and volatility spillover effects on crude oil and natural gas markets. In addition to traditional fossil energy sectors, the relationship between FDI, renewable energy and economic growth are also investigated [17,18]. Magnani and Vaona [19] demonstrated that renewable energy spillover has a positive impact on regional economic growth in Italy. Kathuria et al. [20] applied panel data techniques to investigate the impact of the policy differences on FDI inflow in wind energy. The results showed that the differences have significant resource potential over a seven-year 
period based on empirical research in eight Indian states. Lv and Spigarelli [21] considered FDI as a measure of regional integration of Chinese and European renewable energy sectors. Lee [22] investigated the contributions of FDI net inflows to renewable energy, carbon emissions and economic growth. The results demonstrated that FDI is critical for economic growth. Hassaballa [23] studied the interrelation between FDI inflows and emissions in developing countries. Ming et al. [24] put forward feasible proposals for renewable energy investment and financing issue solutions.

\subsection{Technology Spillover Effects}

In order to quantify the influences of FDI technology spillover, three influencing factors, foreign capital investment, product import, and brand effect were investigated. Lai et al. [25] analyzed the impact of human capital investment and degree of openness of the host country on technology spillovers. Ha et al. [26] proposed an improved model to describe both horizontal and vertical spillover effects by measuring the share of R\&D expenditures. Du et al. [27] explored the effect of industrial policy on FDI spillovers considering subsidized and non-subsidized foreign investment, from the perspective of the magnitude and direction. Foreign capital investment is considered as the main aspect of technology spillover to investigate the technology spillover in Iran [28]. Ramiro and Enrica estimated technology spillover effect from a view of machinery and equipment (M\&E) imports [29]. Lai et al. [30] demonstrated the crucial role of technology absorption capacity on technology spillover effects and brand effect was deemed as the major element of technology spillover in their research. By assessing the impacts of product imports on total factor productivity, Lee et al. [31] found positive impacts of FDI on less developed countries and more prevalent impacts on developed countries. In this paper, we focus on three aspects of FDI renewable energy technology spillover: foreign capital investment, product import and brand effect.

\subsection{Energy Industry Performance}

Since performance is a critical index in evaluating the development level of the energy industry [32,33], it is necessary to study the impact of FDI on the energy industry performance. However, few studies have been conducted in this area. In terms of energy industry performance, Chen et al. [34] considered the relationship among economic, environmental and innovative performances in green technological innovation auditing. Severo et al. [35] proposed a hypothesis that environmental sustainability is positively related to organizational performance and verified this hypothesis through empirical study. Zhao et al. considered the economic performance of waste-to-energy industry in China [36]. Wang and Zhao investigated regional energy-environmental performance for China's non-ferrous metals industry based DEA model [37]. Chen et al. analyzed how external technology sources influenced the innovative performance of Chinese firms [38]. By introducing the three elements (i.e., economic performance, environmental performance and innovative performance) into energy industry performance, this paper aims to fill the current knowledge gap and investigate the impacts of FDI renewable energy technology spillover on performance in China.

FDI technology spillover and renewable energy have been the subjects of intensive studies, and interests in these topics have been growing over recent years. These previous studies make an important contribution to our study. On the basis of a literature review, it can be found that the study on FDI renewable energy technology spillover is very necessary and there is large research space for this study. Therefore, building on previous studies, this paper investigates the impact of FDI renewable energy technology spillover on China's energy industry performance.

\section{Hypotheses and Theoretical Model}

Based on a review of existing studies, the influencing factors of technology spillover are identified, i.e., foreign capital investment, product import and brand effect. Meanwhile, energy industry performance in China is characterized into economic performance, environmental performance and 
innovative performance. This section investigates how FDI renewable energy technology spillover influences energy industry performance in China.

\subsection{The Impacts of Technology Spillover on Economic Performance}

\subsubsection{Foreign Capital Investment}

Foreign capital investment helps to increase the capital stock of energy industry in China, provides funds for the expansion of production scale, the improvement of infrastructure as well as the promoting of workforce level. It thereby promotes the progress of productivity and helps to achieve an increase in economic performance.

\subsubsection{Product Import}

Chen and Dong [39] claimed that import trade has a positive significant impact on economic development. Chen et al. [40] found a significantly positive correlation between product import and economic growth by analyzing the panel data of China. China's energy industry benefits from energy product import and successfully acquires advanced overseas energy production materials and end products. The utilization of foreign renewable energy products decreases the cost of production, increases the rate of finished products and production efficiency, and thereby improves the economic performance.

\subsubsection{Brand Effect}

The expansion of brand effect (i.e., the increase of company registration from overseas renewable energy enterprises) is likely to capture the market shares of energy companies in China. In such a situation, the domestic energy companies are forced to seek technical breakthroughs to face market competition. Meanwhile, the landing of global energy companies initiates cooperation and communication with local energy enterprises, which will expand technology spillover channel and promote economic growth of energy industry in China.

According to the aforementioned analysis, this study proposes Hypothesis 1:

$$
\begin{aligned}
& \mathrm{H}_{1} \text { : FDI renewable energy technology spillover has a positive impact on economic performance of } \\
& \text { energy industry in China. }
\end{aligned}
$$

\subsection{The Impacts of Technology Spillover on Environmental Performance}

\subsubsection{Foreign Capital Investment}

Foreign capital investment used for renewable energy technology will increase the investment of environmental protection, such as the new equipment installation of waste water and solid and the development of production process for low energy consumption and emission. Huang et al. confirmed that FDI from Hong Kong, Macau and Taiwan has a significantly promoting role on environmental outcomes [41]. Researchers also evaluated the environment performance and concluded that FDI, especially the technology-seeking investment, has a positive impact on China's environment [42]. In conclusion, foreign capital investment for renewable energy technology will effectively increase the environmental performance of China's energy industry.

\subsubsection{Product Import}

On the one hand, renewable energy products promote the sustainable development of China's energy industry and product import further enhances the positive situation. On the other hand, the importing of advanced overseas renewable energy may indirectly improve the learning ability of local energy companies, accelerate the R\&D of energy products, and also directly promote the utilization of advanced devices and equipment for renewable energy production. Both of these are 
promising to reduce $\mathrm{CO}_{2}$ emission, sewerage drainage, and energy consumption, and are further improving the environmental performance of China's energy industry.

\subsubsection{Brand Effect}

The registration of overseas companies will expand technology spillover channels of renewable energy through correlation effect, cooperation and competition. It also helps China's energy industry to master the advanced production technology and management methods, and hereby improves environmental performance of energy industry in China via production process and management system.

According to the aforementioned analysis, this study proposes Hypothesis 2:

$\mathrm{H}_{2}$ : FDI renewable energy technology spillover has a positive impact on environmental performance of energy industry in China.

\subsection{The Impacts of Technology Spillover on Innovative Performance}

\subsubsection{Foreign Capital Investment}

The level of technological innovation is positively affected by the amount, type and mode of FDI. More specifically, foreign capital investment provides extra funds for sustainable R\&D of new product and process, therefore increases R\&D technological funds and personnel, so as to promote innovative development of energy industry. Meanwhile, the improvement of science and technology also enhances the technology absorption capacity of China's energy industry and further attracts more special investment from overseas focusing on renewable energy technology innovation. This would form a virtuous circle and continuously improve the innovative performance.

\subsubsection{Product Import}

Product import provides chances for the energy industry of China to approach advanced raw materials, production devices and end products of renewable energy. Through imitation learning and financial support from the innovation funds, the innovative ability of China's energy industry will be significantly improved [43]. Renewable energy product and production technology adopted to China could be developed by acquiring the latest technology and combining China's local situation, and therefore promote innovative performance.

\subsubsection{Brand Effect}

The entry of overseas renewable energy enterprises will improve market concentration and intensify market competition. It also urges China's energy industry to actively develop new products and process, and improve production efficiency in order to achieve fast development of productivity. Meanwhile, transnational energy enterprises bring potential cooperation opportunities with Chinese companies. Through technical communication and project cooperation, Chinese energy enterprises gain new knowledge and technology so as to update current knowledge system and improve technology level. In the process of cooperating and competing with overseas energy companies, the innovative capability of China's energy industry will be improved continuously.

According to the aforementioned analysis, this study proposes Hypothesis 3:

\section{$\mathrm{H}_{3}$ : FDI renewable energy technology spillover has a positive impact on innovative performance of energy industry in China.}

On the basis of previous studies, theoretical analysis and hypotheses, a theoretical model is proposed, as shown in Figure 1. 


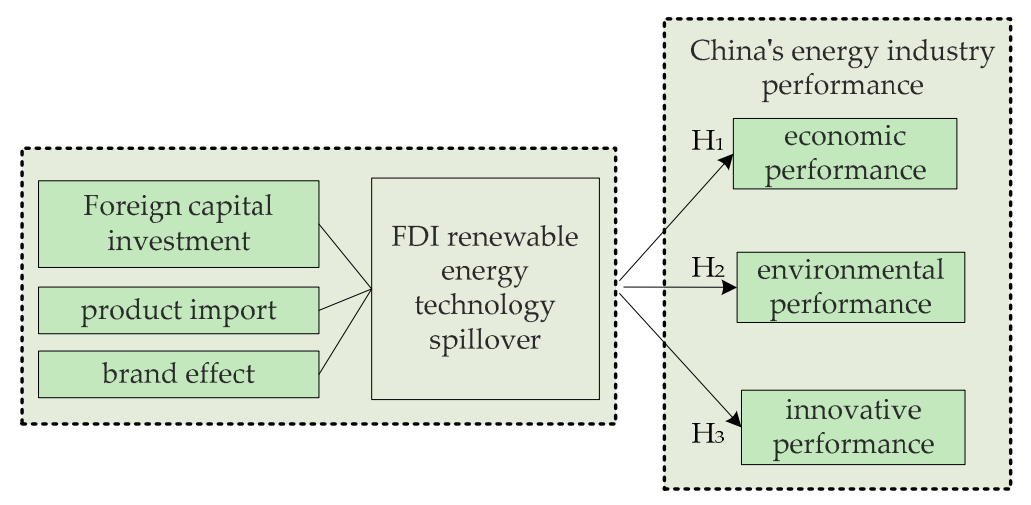

Figure 1. The theoretical model.

\section{Methodology}

\subsection{Mathematical Model}

Factor scores are estimated values in factor analysis. The scores are used to examine the behavior of observations and in other analyses such as regression or MANOVA. DEA is a nonparametric approach in operation research and economics for production frontiers estimation. It is utilized to empirically assess productive efficiency of decision making units and also acts as a classical and common tool to measure performance [44-47]. This paper first applies the factor analysis method to calculate the factor scores of FDI renewable energy technology spillover, and adopts DEA method to obtain energy industry performance in China. The influence coefficients between FDI renewable energy technology spillover and three performances of energy industry are then acquired utilizing the panel data regression analysis method, where a fixed effect variable intercept model is established to analyze the effects of FDI renewable energy technology spillover on energy industry performance in China. Specific models are shown as Equations (1)-(3).

Model 1: Impact model of FDI renewable energy technology spillover on economic performance of energy industry in China,

$$
E C_{i t}=\alpha_{1}+\beta_{1} T S_{i t}+\mu_{i 1}+\varepsilon_{i t 1}
$$

Model 2: Impact model of FDI renewable energy technology spillover on environmental performance of energy industry in China,

$$
E N_{i t}=\alpha_{2}+\beta_{2} T S_{i t}+\mu_{i 2}+\varepsilon_{i t 2}
$$

Model 3: Impact model of FDI renewable energy technology spillover on innovative performance of energy industry in China,

$$
I N_{i t}=\alpha_{3}+\beta_{3} T S_{i t}+\mu_{i 3}+\varepsilon_{i t 3}
$$

where $i$ and $t$ denote region and year respectively. Besides, $\alpha_{j}$ is intercept and $\beta_{j}$ is regression coefficient. $\varepsilon_{i t j}$ is the error term of regression equation, $\mu_{i j}$ is a fixed effect factor which doesn't change all along the time. $T S_{i t}$ denotes FDI renewable energy technology spillover, $E C_{i t}, E N_{i t}$ and $I N_{i t}$ denote economic, environmental and innovative performance of energy industry in China respectively.

\subsection{Data Sources and Index Selection}

In this study, the panel data of 30 different provinces of China from 2005 to 2011 are included. There are 31 provinces in the mainland of China. Since the energy data in Tibet during that period are missing, they are excluded and only 30 provinces are available and considered in the paper. According to available electricity consumption data, Tibet only accounts for $0.05 \%$ of total national electricity consumption. Therefore, the exclusion of Tibet will not undermine the representativeness of this study. 
In addition, the statistical calibers are not completely uniform before 2005; therefore, this paper uses the data of yearbook since 2005. The sample data (2005-2011) is obtained from China New Energy and Renewable Energy Yearbook, China Statistical Yearbook, China Energy Statistical Yearbook, China Statistical Yearbook on Environment and China Statistical Yearbook on Science and Technology).

According to literature review and the analysis in Section 3, FDI renewable energy technology spillover is investigated from foreign capital investment, product import and brand effect; energy industry performance is divided into economic, environmental and innovation performance. Combined with previous studies and data acquisition range from yearbook, capital stock, human resource storage and industry output are combined and used to calculate economic performance; energy consumption, $\mathrm{CO}_{2}$ emissions, solid waste quantity and wastewater quantity are used to calculate environmental performance; and R\&D fund, R\&D personnel and new product output are used to calculate innovative performance, as shown in Tables 1 and 2, in which the explanation, calculation basis and sources of all measurement indexes are presented.

Table 1. Measurement indexes of technology spillover.

\begin{tabular}{|c|c|c|c|c|}
\hline & Index & Index Explanation & Calculation Basis & Data Sources \\
\hline \multirow{3}{*}{ TS } & $\begin{array}{l}\text { foreign } \\
\text { capital } \\
\text { investment }\end{array}$ & $\begin{array}{l}\text { direct capital investment of } \\
\text { foreign firms in renewable } \\
\text { energy industry in China }\end{array}$ & $\begin{array}{l}\text { the sum of "foreign direct investment by } \\
\text { region" in "solar", "wind", "geothermal } \\
\text { energy", "biomass energy" }\end{array}$ & \multirow{3}{*}{$\begin{array}{l}\text { China New Energy } \\
\text { and Renewable } \\
\text { Energy Yearbook }\end{array}$} \\
\hline & $\begin{array}{l}\text { product } \\
\text { import }\end{array}$ & $\begin{array}{l}\text { total imports of renewable } \\
\text { energy products in China }\end{array}$ & $\begin{array}{l}\text { the sum of "total imports of foreign } \\
\text { invested firms in various regions" in } \\
\text { "solar", "wind", "geothermal energy", } \\
\text { "biomass energy" }\end{array}$ & \\
\hline & brand effect & $\begin{array}{l}\text { the benefit and effect brought } \\
\text { by using the original brands } \\
\text { from FDI firms }\end{array}$ & $\begin{array}{l}\text { the sum of "registration number of foreign } \\
\text { investment firms in various regions by the } \\
\text { end of the year" in "solar", "wind", } \\
\text { "geothermal energy", "biomass energy" }\end{array}$ & \\
\hline
\end{tabular}

Notes: TS denotes FDI renewable energy technology spillover.

Table 2. Measurement indexes of energy industry performance.

\begin{tabular}{|c|c|c|c|c|}
\hline & Index & Index Explanation & Calculation Basis & Data Sources \\
\hline \multirow{3}{*}{$\mathrm{EC}$} & capital stock $[48,49]$ & $\begin{array}{l}\text { total capital resources of } \\
\text { the enterprises }\end{array}$ & $\begin{array}{l}\text { the sum of "total assets of industrial enterprises above } \\
\text { designated size by region" }\end{array}$ & \multirow{4}{*}{$\begin{array}{l}\text { China } \\
\text { Statistical } \\
\text { Yearbook }\end{array}$} \\
\hline & $\begin{array}{l}\text { human resource } \\
\text { storage }[50,51]\end{array}$ & $\begin{array}{l}\text { total human resources of } \\
\text { the enterprises }\end{array}$ & $\begin{array}{l}\text { the sum of "employed persons of industrial enterprises } \\
\text { above designated size by region" }\end{array}$ & \\
\hline & $\begin{array}{l}\text { industry output } \\
{[52,53]}\end{array}$ & $\begin{array}{l}\text { the total product value of energy } \\
\text { industry in a certain period } \\
\text { of time }\end{array}$ & $\begin{array}{l}\text { the sum of "gross output value of industrial enterprises } \\
\text { above designated size by region" }\end{array}$ & \\
\hline \multirow{4}{*}{ EN } & $\begin{array}{l}\text { energy } \\
\text { consumption } \\
{[54,55]}\end{array}$ & $\begin{array}{l}\text { consumption of coal, oil, natural } \\
\text { gas, water and electricity in } \\
\text { production process }\end{array}$ & the sum of "energy consumption by region" & \\
\hline & $\begin{array}{l}\mathrm{CO}_{2} \text { emissions } \\
{[56-58]}\end{array}$ & $\begin{array}{l}\mathrm{CO}_{2} \text { emissions in } \\
\text { production process }\end{array}$ & $\begin{array}{l}\text { IPCC based on the sum of "coal consumption by } \\
\text { region", "oil consumption by region" and "natural gas } \\
\text { consumption by region" }\end{array}$ & $\begin{array}{l}\text { China Energy } \\
\text { Statistical } \\
\text { Yearbook }\end{array}$ \\
\hline & $\begin{array}{l}\text { solid waste } \\
\text { quantity [56-58] }\end{array}$ & $\begin{array}{l}\text { solid waste generated in the } \\
\text { production process of } \\
\text { energy industry }\end{array}$ & $\begin{array}{l}\text { the sum of "general industrial solid waste utilization } \\
\text { and disposal by region" }\end{array}$ & \multirow{2}{*}{$\begin{array}{l}\text { China } \\
\text { Statistical } \\
\text { Yearbook on } \\
\text { Environment }\end{array}$} \\
\hline & $\begin{array}{l}\text { wastewater } \\
\text { quantity [56-58] }\end{array}$ & $\begin{array}{l}\text { wastewater generated in the } \\
\text { production process of } \\
\text { energy industry }\end{array}$ & the sum of "industrial wastewater disposal by region" & \\
\hline \multirow{3}{*}{ IN } & R\&D fund [59-61] & $\begin{array}{l}\text { R\&D expenditures for the } \\
\text { energy industry }\end{array}$ & $\begin{array}{l}\text { the sum of "R\&D funds of industrial enterprises above } \\
\text { designated size by region" }\end{array}$ & \multirow{3}{*}{$\begin{array}{c}\text { China } \\
\text { Statistical } \\
\text { Yearbook on } \\
\text { Science and } \\
\text { Technology }\end{array}$} \\
\hline & $\begin{array}{l}\text { R\&D personnel } \\
{[59,62,63]}\end{array}$ & $\begin{array}{l}\text { number of R\&D personnel for the } \\
\text { energy industry }\end{array}$ & $\begin{array}{l}\text { the sum of "R\&D personnel of industrial enterprises } \\
\text { above designated size by region" }\end{array}$ & \\
\hline & $\begin{array}{l}\text { new product } \\
\text { output }[59,64,65]\end{array}$ & $\begin{array}{l}\text { new product output value of } \\
\text { energy industry }\end{array}$ & $\begin{array}{l}\text { the sum of "gross output value of new products of large } \\
\text { and medium sized industrial enterprises by region" }\end{array}$ & \\
\hline
\end{tabular}

Notes: All the data are selected from "coal mining and washing industry", "petroleum and natural gas extraction industry", "petroleum processing, coking, nucleus fuel processing industry", "electric power, heat power production and supply industry", "gas production and distribution industry" and "water production and distribution industry" of China's yearbook. EC denotes economic performance, EN denotes environmental performance, and IN denotes innovative performance. 
Moreover, in order to observe the changes over time, a descriptive statistical analysis of the measurement indexes is complemented (Due to the dimensions of the indexes are different, all the indexes have been standardized). Figures 2 and 3 display the averages and standard deviations of 13 measurement indexes for 30 provinces from 2005 to 2011 . It can be seen from the two graphs that these indexes present an ascending trend as a whole along with the time process.

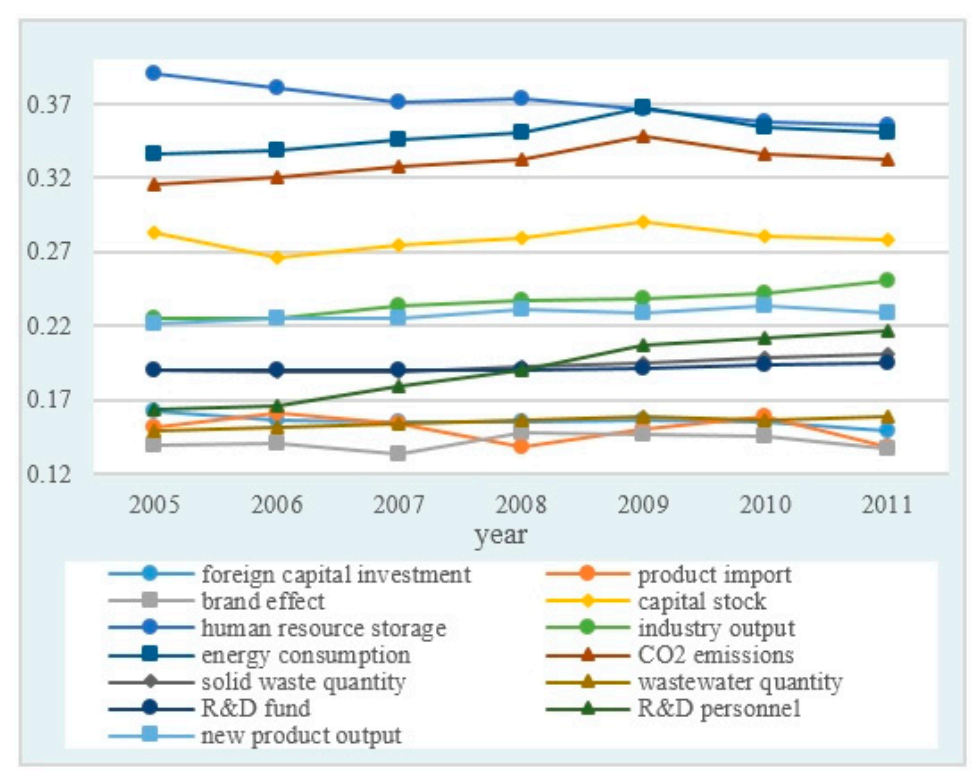

Figure 2. Mean of measurement indexes.

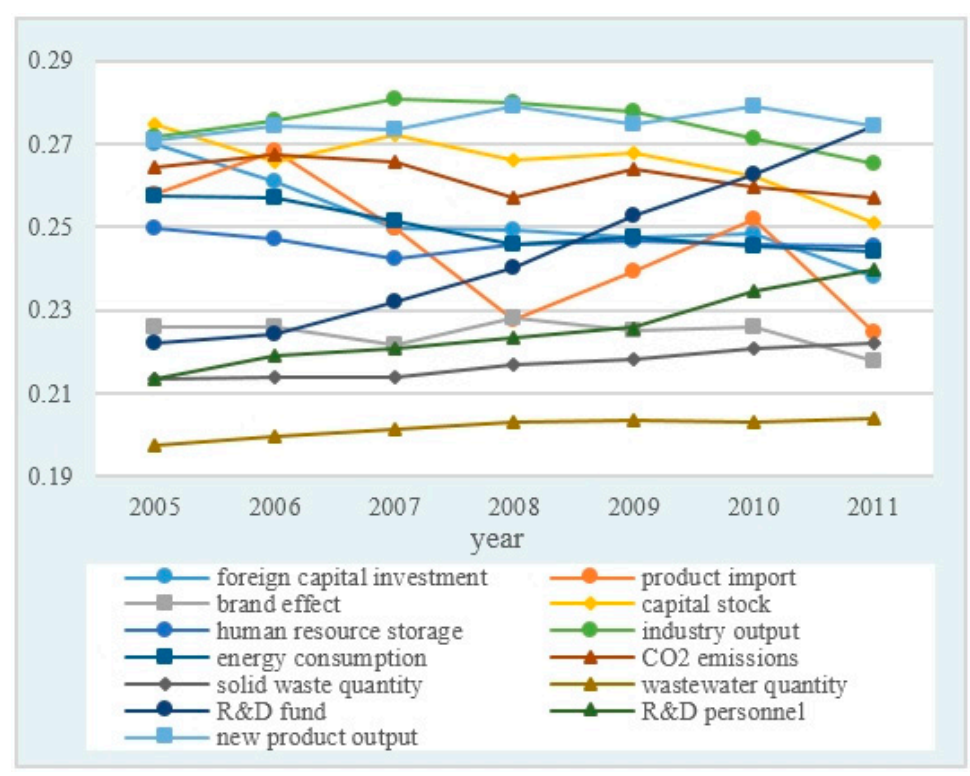

Figure 3. Standard deviation of measurement indexes.

\section{Empirical Results and Discussion}

\subsection{FDI Renewable Energy Technology Spillover}

This study adopted factor analysis method and used statistic software SPSS 17.0 (IBM, Armonk, NY, USA) to calculate FDI renewable energy technology spillover in 30 different provinces of China from 2005 to 2011. Firstly, we normalized the data, and then put the processed data into factor analysis model using software SPSS 17.0. KMO reaches 0.748 , the approximate chi square value in the Bartlett 
ball test is 1078.833 (df-3), significance level $p=0.000<0.05$, cumulative variance contribution rate of factors reaches $96.672 \%$. Finally, we used the numerical regression method and obtained the factor score function of technology spillover, as shown in Equation (4). After putting the values of foreign capital investment, product import and brand effect into Equation (4), we can obtain comprehensive factor scores for FDI renewable energy technology spillover, as shown in Table 3.

$$
F=0.342 X_{1}+0.337 X_{2}+0.339 X_{3}
$$

where $F$ represents the factor score of technology spillover, $X_{1}$ represents foreign capital investment, $X_{2}$ represents product import, and $X_{3}$ represents brand effect.

Table 3. FDI renewable energy technology spillover in 30 different provinces of China.

\begin{tabular}{cccccccc}
\hline Region & $\mathbf{2 0 0 5}$ & $\mathbf{2 0 0 6}$ & $\mathbf{2 0 0 7}$ & $\mathbf{2 0 0 8}$ & $\mathbf{2 0 0 9}$ & $\mathbf{2 0 1 0}$ & $\mathbf{2 0 1 1}$ \\
\hline Beijing & 5.109 & 7.303 & 5.316 & 5.683 & 4.605 & 5.982 & 5.208 \\
Tianjin & 4.624 & 6.804 & 5.458 & 5.710 & 4.589 & 6.199 & 5.433 \\
Hebei & 3.938 & 4.946 & 4.165 & 4.591 & 3.303 & 4.695 & 4.571 \\
Shanxi & 3.639 & 4.206 & 3.923 & 3.926 & 2.821 & 4.224 & 4.110 \\
Inner Mongolia & 3.422 & 4.434 & 3.608 & 4.427 & 3.749 & 4.026 & 4.189 \\
Liaoning & 3.160 & 5.308 & 3.838 & 4.302 & 3.421 & 4.56 & 3.992 \\
Jilin & 3.408 & 4.295 & 4.484 & 3.861 & 3.632 & 4.355 & 4.270 \\
Heilongjiang & 3.347 & 5.191 & 3.434 & 4.064 & 2.924 & 4.500 & 4.120 \\
Shanghai & 5.098 & 6.402 & 5.103 & 5.386 & 3.994 & 5.935 & 4.898 \\
Jiangsu & 4.808 & 6.214 & 5.423 & 6.060 & 4.771 & 5.805 & 5.467 \\
Zhejiang & 4.805 & 5.747 & 5.030 & 4.890 & 4.125 & 5.642 & 4.947 \\
Anhui & 3.803 & 4.390 & 3.775 & 4.319 & 3.502 & 4.115 & 4.190 \\
Fujian & 3.605 & 4.430 & 3.487 & 4.179 & 3.281 & 4.390 & 4.294 \\
Jiangxi & 3.675 & 4.831 & 4.145 & 3.706 & 3.531 & 4.559 & 4.179 \\
Shandong & 4.614 & 6.052 & 5.287 & 5.301 & 4.664 & 5.398 & 5.403 \\
Henan & 3.801 & 4.698 & 4.138 & 3.791 & 3.215 & 4.308 & 4.154 \\
Hubei & 3.699 & 4.463 & 3.781 & 4.275 & 3.118 & 4.962 & 4.383 \\
Hunan & 4.029 & 4.523 & 3.979 & 3.995 & 3.507 & 4.373 & 4.456 \\
Guangdong & 4.736 & 5.919 & 5.165 & 5.238 & 4.422 & 5.573 & 5.153 \\
Guangxi & 3.694 & 4.829 & 3.539 & 3.852 & 3.369 & 4.337 & 4.311 \\
Hainan & 2.831 & 4.372 & 4.884 & 3.951 & 3.041 & 4.131 & 3.880 \\
Chongqing & 3.859 & 4.090 & 3.992 & 3.997 & 3.578 & 4.354 & 4.254 \\
Sichuan & 4.190 & 5.211 & 4.158 & 4.207 & 4.028 & 4.329 & 4.885 \\
Guizhou & 4.011 & 4.679 & 4.529 & 4.064 & 3.816 & 4.474 & 4.677 \\
Yunnan & 3.560 & 4.487 & 3.854 & 3.564 & 2.974 & 4.107 & 3.88 \\
Shaanxi & 3.888 & 4.311 & 3.697 & 3.985 & 3.080 & 4.207 & 4.192 \\
Gansu & 3.563 & 4.714 & 4.052 & 3.489 & 3.006 & 4.240 & 4.126 \\
Qinghai & 3.554 & 4.881 & 3.905 & 3.985 & 2.777 & 4.576 & 4.348 \\
Ningxia & 3.574 & 3.994 & 3.743 & 3.681 & 2.943 & 4.413 & 4.390 \\
Xinjiang & 3.660 & 4.862 & 3.341 & 3.815 & 2.772 & 4.347 & 4.182 \\
\hline & & & & & & & \\
\hline & & & & & \\
Huan
\end{tabular}

From Table 3, it can be found that economic and technological developed regions, such as Beijing, Tianjin, Shanghai, Shandong, Guangdong and other eastern coast areas have higher factor scores for technology spillover than other regions, all above 4.8 in 2011. One of the probable reasons is that these provinces are located close to the port and international airport, and always pay abundant attention to foreign investment. Moreover, their economic and technological development levels are comparatively higher in China. Accordingly, these provinces have more opportunities for technology spillover than other provinces. Central and northeastern regions including Jiangxi, Hubei, Hunan, Henan, Heilongjiang, Jilin and Liaoning form the second ranking group. Their factor scores of technology spillover are between 3.9 and 4.5 in 2011. This is because their technology spillover is determined and also limited by their geographic location and the development level of technology and economy to a certain extent. Unsurprisingly, western regions such as Gansu, Xinjiang and Shaanxi etc. have 
the lower factor scores, only between 3.1 and 4.2 in 2011. The conceivable reason is that they are located inland and have fewer chances to attract foreign trade. Also, western areas of China attach more importance to exploit natural resources in their own provinces' for a long time which leads to relatively lower dependence on the foreign trade.

\subsection{Energy Industry Performance in China}

This study employs data processing software DEAP 2.1 to calculate energy industry performance in 30 different provinces of China from 2005 to 2011, and obtains economic performance, environmental performance and innovative performance. Economic performance situation of energy industry is shown in Table 4. Environmental performance and innovative performance situations are similar to economic performance. Due to space limitation, environmental performance and innovative performance situations are not detailed in this paper.

Table 4. Economic performance of energy industry in 30 different provinces of China.

\begin{tabular}{|c|c|c|c|c|c|c|c|}
\hline Region & 2005 & 2006 & 2007 & 2008 & 2009 & 2010 & 2011 \\
\hline Beijing & 0.953 & 1.342 & 0.989 & 1.063 & 0.843 & 1.138 & 0.974 \\
\hline Tianjin & 0.899 & 1.263 & 0.996 & 1.076 & 0.842 & 1.222 & 1.037 \\
\hline Hebei & 0.987 & 1.162 & 0.993 & 1.096 & 0.807 & 1.145 & 1.099 \\
\hline Shanxi & 0.967 & 1.104 & 1.028 & 1.066 & 0.744 & 1.200 & 1.102 \\
\hline Inner Mongolia & 0.900 & 1.196 & 1.007 & 1.168 & 0.995 & 1.099 & 1.138 \\
\hline Liaoning & 0.877 & 1.391 & 1.040 & 1.101 & 0.935 & 1.220 & 1.086 \\
\hline Jilin & 0.923 & 1.170 & 1.182 & 1.059 & 0.974 & 1.168 & 1.139 \\
\hline Heilongjiang & 0.874 & 1.407 & 0.935 & 1.065 & 0.782 & 1.176 & 1.082 \\
\hline Shanghai & 1.005 & 1.317 & 1.038 & 1.094 & 0.834 & 1.220 & 0.976 \\
\hline Jiangsu & 1.006 & 1.282 & 1.109 & 1.185 & 0.950 & 1.193 & 1.089 \\
\hline Zhejiang & 0.972 & 1.176 & 0.998 & 1.007 & 0.834 & 1.136 & 1.041 \\
\hline Anhui & 1.007 & 1.149 & 1.018 & 1.116 & 0.917 & 1.151 & 1.179 \\
\hline Fujian & 0.974 & 1.168 & 0.963 & 1.078 & 0.893 & 1.159 & 1.102 \\
\hline Jiangxi & 1.005 & 1.359 & 1.094 & 1.023 & 0.974 & 1.227 & 1.116 \\
\hline Shandong & 0.965 & 1.267 & 1.039 & 1.080 & 0.911 & 1.098 & 1.076 \\
\hline Henan & 1.020 & 1.286 & 1.127 & 1.035 & 0.867 & 1.129 & 1.113 \\
\hline Hubei & 0.977 & 1.190 & 0.987 & 1.123 & 0.859 & 1.361 & 1.192 \\
\hline Hunan & 1.062 & 1.240 & 1.080 & 1.075 & 0.941 & 1.169 & 1.193 \\
\hline Guangdong & 0.937 & 1.174 & 1.034 & 1.078 & 0.885 & 1.100 & 1.046 \\
\hline Guangxi & 0.981 & 1.322 & 0.963 & 1.076 & 0.916 & 1.178 & 1.156 \\
\hline Hainan & 0.769 & 1.179 & 1.272 & 1.054 & 0.829 & 1.107 & 1.096 \\
\hline Chongqing & 1.050 & 1.102 & 1.061 & 1.071 & 0.938 & 1.144 & 1.144 \\
\hline Sichuan & 1.002 & 1.271 & 1.047 & 1.023 & 0.978 & 1.096 & 1.167 \\
\hline Guizhou & 0.952 & 1.149 & 1.066 & 0.972 & 0.918 & 1.111 & 1.141 \\
\hline Yunnan & 0.924 & 1.246 & 1.000 & 0.992 & 0.821 & 1.127 & 1.073 \\
\hline Shaanxi & 1.016 & 1.180 & 1.003 & 1.015 & 0.856 & 1.166 & 1.115 \\
\hline Gansu & 0.948 & 1.260 & 1.078 & 0.956 & 0.808 & 1.129 & 1.105 \\
\hline Qinghai & 0.955 & 1.303 & 1.049 & 1.111 & 0.765 & 1.247 & 1.167 \\
\hline Ningxia & 0.959 & 1.076 & 1.001 & 0.981 & 0.769 & 1.164 & 1.129 \\
\hline Xinjiang & 0.971 & 1.347 & 0.915 & 1.016 & 0.760 & 1.159 & 1.098 \\
\hline
\end{tabular}

The results in Table 4 show that energy industry performance in China is able to maintain the overall level higher than 1.000 every year. This suggests that energy industry performance in China is rising steadily. In addition, it also can be found that energy industry performances of 30 different provinces of China in 2009 are less than 1, which suggests that China's energy industry performance is not very efficient in 2009. The probable reason is that the development of energy industry is negatively affected by global financial crisis in the according year. 


\subsection{Regression Results}

First, this paper implemented stationarity test of panel data, specifically including LLC and PP-Fisher test, and then carried out a Hausman test, and the test results are shown in Tables 5 and 6. Finally, this paper employs econometric software Eviews 6.0 (IHS, Irvine, CA, USA) to carry out mathematical regression analysis using the panel data shown in Sections 5.1 and 5.2. The regression results of FDI renewable energy technology spillover impacting energy industry performance in 30 different provinces of China are shown in Table 7.

Table 5. The stationarity test results.

\begin{tabular}{ccc}
\hline & LLC Test & PP-Fisher Test \\
\hline Economic performance & $-19.7535^{* * *}(0.0000)$ & $207.239^{* * *}(0.0000)$ \\
Environmental performance & $-20.0364^{* * *}(0.0000)$ & $234.115^{* * *}(0.0000)$ \\
Innovative performance & $-19.4577^{* * *}(0.0000)$ & $215.263^{* * *}(0.0000)$ \\
Technology spillover & $-20.3482^{* *}(0.0000)$ & $199.859^{* *}(0.0000)$ \\
\hline
\end{tabular}

Notes: ${ }^{* * *} p<0.01$.

Table 6. Hausman test results summary.

\begin{tabular}{ccccc}
\hline \multirow{2}{*}{ Model 1 } & Test summary & chi-square test & freedom degree & significance test \\
& Cross-section random & 585.042441 & 1 & 0.0000 \\
\hline \multirow{2}{*}{ Model 2 } & Test summary & chi-square test & freedom degree & significance test \\
& Cross-section random & 558.373330 & 1 & 0.0000 \\
\hline \multirow{2}{*}{ Model 3 } & Test summary & chi-square test & freedom degree & significance test \\
& Cross-section random & 573.166244 & 1 & 0.0000 \\
\hline
\end{tabular}

Table 7. Regression results.

\begin{tabular}{|c|c|c|c|}
\hline & Economic Performance & Environmental Performance & Innovative Performance \\
\hline Sample number & 210 & 210 & 210 \\
\hline Constant & 0.028 & 0.032 & 0.035 \\
\hline TS & $0.239 * * *$ & $0.216^{* * *}$ & $0.227^{* * *}$ \\
\hline$R^{2} /$ adjusted $R^{2}$ & $0.957 / 0.950$ & $0.948 / 0.939$ & $0.955 / 0.948$ \\
\hline DW statistic & 2.513 & 2.126 & 2.415 \\
\hline \multicolumn{4}{|l|}{ Fixed effect } \\
\hline Beijing & -0.325 & -0.293 & -0.308 \\
\hline Tianjin & -0.307 & -0.277 & -0.291 \\
\hline Hebei & -0.019 & -0.018 & -0.018 \\
\hline Shanxi & 0.084 & 0.076 & 0.080 \\
\hline Inner Mongolia & 0.092 & 0.083 & 0.087 \\
\hline Liaoning & 0.088 & 0.080 & 0.084 \\
\hline Jilin & 0.092 & 0.084 & 0.088 \\
\hline Heilongiiang & 0.075 & 0.067 & 0.071 \\
\hline Shanghai & -0.217 & -0.196 & -0.206 \\
\hline Jiangsu & -0.229 & -0.206 & -0.217 \\
\hline Zhejiang & -0.207 & -0.187 & -0.197 \\
\hline Anhui & 0.088 & 0.080 & 0.084 \\
\hline Fujian & 0.075 & 0.067 & 0.071 \\
\hline Jiangxi & 0.108 & 0.097 & 0.102 \\
\hline Shandong & -0.221 & -0.199 & -0.209 \\
\hline Henan & 0.094 & 0.085 & 0.089 \\
\hline Hubei & 0.090 & 0.082 & 0.086 \\
\hline Hunan & 0.094 & 0.085 & 0.090 \\
\hline Guangdong & -0.229 & -0.207 & -0.218 \\
\hline Guangxi & 0.102 & 0.092 & 0.097 \\
\hline Hainan & 0.090 & 0.082 & 0.085 \\
\hline Chongqing & 0.084 & 0.076 & 0.079 \\
\hline Sichuan & -0.004 & -0.004 & -0.004 \\
\hline Guizhou & -0.018 & -0.016 & -0.017 \\
\hline Yunnan & 0.095 & 0.085 & 0.090 \\
\hline Shaanxi & 0.087 & 0.078 & 0.082 \\
\hline Gansu & 0.083 & 0.075 & 0.079 \\
\hline Qinghai & 0.099 & 0.090 & 0.094 \\
\hline Ningxia & 0.069 & 0.062 & 0.065 \\
\hline Xinjiang & 0.088 & 0.079 & 0.083 \\
\hline
\end{tabular}


According to the regression results of panel data model, corresponding equations of economic performance, environmental performance and innovative performance are shown as Equations (5)-(7).

$$
\begin{gathered}
E C_{i t}=0.028+0.239 T S_{i t}-0.325 D_{1}-0.307 D_{2}+\ldots+0.088 D_{30}+\varepsilon_{i t 1} \\
R^{2}=0.957, \mathrm{SSE}=0.315 \\
E N_{i t}=0.032+0.216 T S_{i t}-0.293 D_{1}-0.277 D_{2}+\ldots+0.079 D_{30}+\varepsilon_{i t 2} \\
R^{2}=0.948, \mathrm{SSE}=0.153 \\
I N_{i t}=0.035+0.227 T S_{i t}-0.308 D_{1}-0.291 D_{2}+\ldots+0.083 D_{30}+\varepsilon_{i t 3} \\
R^{2}=0.955, \mathrm{SSE}=0.144
\end{gathered}
$$

where $T S_{i t}$ denotes FDI renewable energy technology spillover, $E C_{i t}, E N_{i t}$ and $I N_{i t}$ denote economic, environmental and innovative performance of energy industry in China respectively.

As can be clearly seen from the regression results in Figure 4, the regression coefficients of FDI renewable energy technology spillover and three performances are all positive. Meanwhile, the results are significant. It can be concluded that FDI renewable energy technology spillover has positive impacts on Chinese energy industry performance. Accordingly, the hypotheses $H_{1}, H_{2}$ and $H_{3}$ can be confirmed. Furthermore, the effects of FDI renewable energy technology spillover on the individual indicators of economic, environment and innovative performance are examined, and the results are significant, as shown in Table 8.

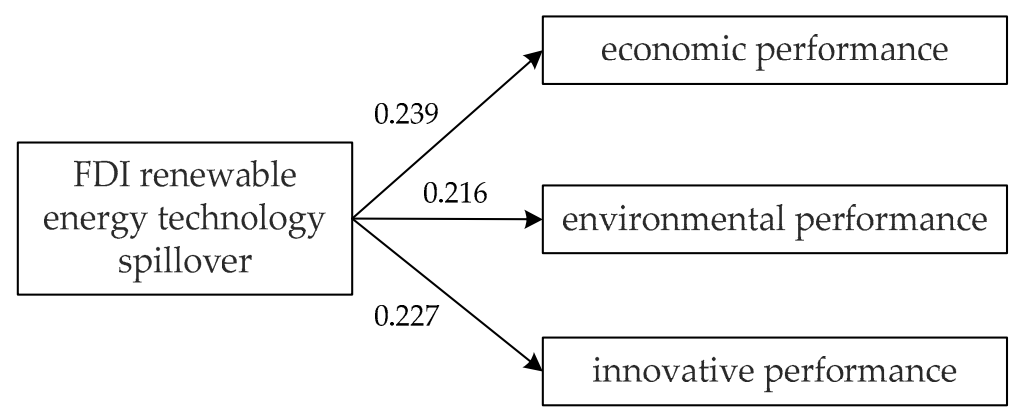

Figure 4. Regression results.

Table 8. The effects of technology spillover on individual indicators.

\begin{tabular}{lccccc}
\hline & Capital Stock & $\begin{array}{c}\text { Human } \\
\text { Resource Storage }\end{array}$ & $\begin{array}{c}\text { Industry } \\
\text { Output }\end{array}$ & $\begin{array}{c}\text { Energy } \\
\text { Consumption }\end{array}$ & $\begin{array}{c}\mathrm{CO}_{2} \\
\text { Emissions }\end{array}$ \\
\hline Correlations & 0.534 & 0.503 & 0.511 & 0.329 & 0.227 \\
significance & 0.000 & 0.000 & 0.000 & 0.000 & 0.003 \\
\hline & Solid Waste & Wastewater & R\&D Fund & R\&D & New Product \\
& Quantity & Quantity & Personnel & Output \\
\hline Correlations & 0.341 & 0.213 & 0.515 & 0.498 & 0.590 \\
significance & 0.000 & 0.004 & 0.000 & 0.000 & 0.000 \\
\hline
\end{tabular}

The results show that FDI renewable energy technology spillover has the largest impact on economic performance, and the regression coefficient is 0.239 . This means that when FDI renewable energy technology spillover increases $1 \%$, the economic performance of China's energy industry will increase $0.239 \%$ accordingly. Meanwhile, the regression coefficients of FDI renewable energy technology spillover with environmental performance and innovative performance are 0.216 and 0.227 respectively. That is to say when FDI renewable energy technology spillover increases $1 \%$, environmental performance and innovative performance will increase $0.216 \%$ and $0.227 \%$ respectively. 
Among the indicators of economic, environmental and innovative performance, FDI renewable energy technology spillover has the largest impact on new product output and the least impact on wastewater quantity.

The reason why the impact of FDI renewable energy technology spillover on economic performance is larger than environmental and innovative performance is that three influencing factors of technology spillover have the most direct and effective impacts on economic performance promotion. More specifically, foreign capital investment provides funds for energy industry and enterprise to enlarge reproduction, which has direct impacts on infrastructure construction and labor instruments improvement. Product import and brand effect, to a certain extent, promote market competitiveness of renewable energy products compared with traditional energy products in China. Accordingly, the total outputs can be promoted. Therefore, product import and brand effect affect economic performance of energy industry eventually. Moreover, compared with economic performance, the impacts of FDI renewable energy technology spillover on environmental performance and innovative performance are also meaningful and thus cannot be neglected. Capital investment for expanding innovation and environmental protection, imitation learning from foreign advanced renewable energy products and the demonstration effect of foreign enterprises will have positive effects on environment performance and innovative performance of China's energy industry.

\section{Conclusions and Policy Implications}

This paper investigated the impacts of FDI renewable energy technology spillover on energy industry performance in China. Based on three hypotheses, a theoretical model is proposed to quantify the impacts. Furthermore, an empirical test was carried out using the panel data regression model to measure the impacts from 2005 to 2011. It is shown that FDI renewable energy technology spillover has positive impacts on China's energy industry performance. Out of the three performances, FDI renewable energy technology spillover has the largest impact on economic performance. It was also found that economic and technological developed regions have higher factor scores for technology spillover, which means more obvious technology spillover effects are shown in these regions. The factor scores of technology spillover in economically and technologically less developed areas are lower. The results demonstrate that China's energy industry performance can be enhanced by promoting FDI renewable energy technology spillover.

According to the key findings of this paper, some policy implications are proposed as references for decision-making by policy makers in different areas of China.

(1) In order to vitalize China's energy industry, governments and enterprises can take measures to promote the development of FDI renewable energy technology spillover, such as enhancing the supervision strength of FDI process, improving the investment climate, completing the market economic system, and encouraging the imports of renewable energy products.

(2) To speed up renewable energy technology spillover in the western region of China, the Chinese government is expected to encourage renewable energy technology exchange and cooperation between the eastern and western areas of China, such as promoting the collaborative construction of industrial parks and depending on the existing development zones and high-tech parks. By encouraging foreign trade in the western region of China, FDI renewable energy technology spillover can be enhanced, which will also improve energy industry performance in China.

(3) It is significant for China to adopt differentiated foreign trade policy and technical preferential policy in order to encourage the transformation and diffusion of FDI renewable energy technology towards inland border areas.

(4) The processing trade industry of eastern coastal regions should be encouraged to move to inland border areas. These policies will promote the development and execution of China's "One Belt, One Road" initiative as well.

Acknowledgments: This research was funded by the National Natural Science Foundation of China (71302028), (71602041). 
Author Contributions: Jing Xing collected the data; Xiandong $\mathrm{Xu}$ and Zhile Yang polished the language; Weiwei Liu and Jianyu Zhao analyzed results with economic interpretation; Weiwei Liu wrote the paper. All the authors read and approved the final manuscript.

Conflicts of Interest: The authors declare no conflict of interest.

\section{References}

1. The Organisation for Economic Co-Operation and Development (OECD). China Go Global. 2014. Available online: http:/ / www.Oecd.Org/china/china-go-global.htm (accessed on 21 March 2014).

2. Ackah, I.; Kizys, R. Green growth in oil producing African countries: A panel data analysis of renewable energy demand. Renew. Sustain. Energy Rev. 2015, 50, 1157-1166. [CrossRef]

3. Huang, P.; Negro, S.O.; Hekkert, M.P.; Bi, K.X. How China became a leader in solar PV: An innovation system analysis. Renew. Sustain. Energy Rev. 2016, 64, 777-789. [CrossRef]

4. Petinrin, J.O.; Shaaban, M. Renewable energy for continuous energy sustainability in Malaysia. Renew. Sustain. Energy Rev. 2015, 50, 967-981. [CrossRef]

5. Pfenninger, S.; Keirstead, J. Renewables, nuclear, or fossil fuels? Scenarios for great Britain's power system considering costs, emissions and energy security. Appl. Energy 2015, 152, 83-93. [CrossRef]

6. Tientao, A.; Legros, D.; Pichery, M.C. Technology Spillover and TFP growth: A Spatial Durbin Model. Int. Econ. 2015, 145, 21-31. [CrossRef]

7. Fujimori, A.; Sato, T. Productivity and technology diffusion in India: The spillover effects from foreign direct investment. J. Policy Model. 2015, 37, 630-651. [CrossRef]

8. Wan, J.; Baylis, K.; Mulder, P. Trade-facilitated technology spillovers in energy productivity convergence processes across EU countries. Energy Econ. 2015, 48, 253-264. [CrossRef]

9. Krammer, S.M.S. Do good institutions enhance the effect of technological spillovers on productivity? Comparative evidence from developed and transition economies. Technol. Forecast. Soc. Chang. 2015, 94, 133-154. [CrossRef]

10. Kim, H.-H.; Lee, H.; Lee, J. Technology diffusion and host-country productivity in South-South FDI flows. Jpn. World Econ. 2015, 33, 1-10. [CrossRef]

11. Newman, C.; Rand, J.; Talbot, T.; Tarp, F. Technology transfers, foreign investment and productivity spillovers. Eur. Econ. Rev. 2015, 76, 168-187. [CrossRef]

12. Fernandes, A.M.; Paunov, C. Foreign direct investment in services and manufacturing productivity: Evidence for Chile. J. Dev. Econ. 2012, 97, 305-321. [CrossRef]

13. Seck, A. International technology diffusion and economic growth: Explaining the spillover benefits to developing countries. Struct. Chang. Econ. Dyn. 2012, 23, 437-451. [CrossRef]

14. Ouyang, P.; Fu, S.H. Economic growth, local industrial development and inter-regional spillovers from foreign direct investment: Evidence from China. China Econ. Rev. 2012, 23, 445-460. [CrossRef]

15. Bai, C.E.; Ma, H.; Pan, W.Q. Spatial spillover and regional economic growth in China. China Econ. Rev. 2012, 23, 982-990. [CrossRef]

16. Lin, B.; Li, J. The spillover effects across natural gas and oil markets: Based on the VEC-MGARCH framework. Appl. Energy 2015, 155, 229-241. [CrossRef]

17. Sbia, R.; Shahbaz, M.; Hamdi, H. A contribution of foreign direct investment, clean energy, trade openness, carbon emissions and economic growth to energy demand in UAE. Econ. Model. 2014, 36, 191-197. [CrossRef]

18. Doytch, N.; Narayan, S. Does FDI influence renewable energy consumption? An analysis of sectoral FDI impact on renewable and non-renewable industrial energy consumption. Energy Econ. 2016, 54, $291-301$. [CrossRef]

19. Magnani, N.; Vaona, A. Regional spillover effects of renewable energy generation in Italy. Energy Policy 2013, 56, 663-671. [CrossRef]

20. Kathuria, V.; Ray, P.; Bhangaonkar, R. FDI (foreign direct investment) in wind energy sector in India: Testing the effectiveness of state policies using panel data. Energy 2015, 80, 190-202. [CrossRef]

21. Lv, P.; Spigarelli, F. The integration of Chinese and European renewable energy markets: The role of Chinese foreign direct investments. Energy Policy 2015, 81, 14-26. [CrossRef]

22. Lee, J.W. The contribution of foreign direct investment to clean energy use, carbon emissions and economic growth. Energy Policy 2013, 55, 483-489. [CrossRef] 
23. Hassaballa, $\mathrm{H}$. Testing for granger causality between energy use and foreign direct investment inflows in developing countries. Renew. Sustain. Energy Rev. 2014, 31, 417-426. [CrossRef]

24. Ming, Z.; Ximei, L.; Yulong, L.; Lilin, P. Review of renewable energy investment and financing in China: Status, mode, issues and countermeasures. Renew. Sustain. Energy Rev. 2014, 31, 23-37. [CrossRef]

25. Lai, M.; Peng, S.; Bao, Q. Technology spillovers, absorptive capacity and economic growth. China Econ. Rev. 2006, 17, 300-320. [CrossRef]

26. Ha, Y.J.; Giroud, A. Competence-creating subsidiaries and FDI technology spillovers. Int. Bus. Rev. 2015, 24, 605-614. [CrossRef]

27. Du, L.; Harrison, A.; Jefferson, G. FDI spillovers and industrial policy: The role of tariffs and tax holidays. World Dev. 2014, 64, 366-383. [CrossRef]

28. Salim, A.; Razavi, M.R.; Afshari-Mofrad, M. Foreign direct investment and technology spillover in Iran: The role of technological capabilities of subsidiaries. Technol. Forecast. Soc. Chang. 2015, in press. [CrossRef]

29. Parrado, R.; Cian, E.D. Technology spillovers embodied in international trade: Intertemporal, regional and sectoral effects in a global cge framework. Energy Econ. 2014, 41, 76-89. [CrossRef]

30. Lai, M.; Bao, Q.; Peng, S.; Zhang, X. Foreign direct investment and technology spillover: Based on the study of technology absorption capacity. Econ. Res. J. 2005, 8, 95-105.

31. Lee, H.; Lee, J.; Kim, H.-H. Foreign direct investment, technology diffusion, and host country productivity growth. Asian Dev. Bank Econ. Work. Pap. Ser. 2011. [CrossRef]

32. Hong, T.; Koo, C.; Kim, J.; Lee, M.; Jeong, K. A review on sustainable construction management strategies for monitoring, diagnosing, and retrofitting the building's dynamic energy performance: Focused on the operation and maintenance phase. Appl. Energy 2015, 155, 671-707. [CrossRef]

33. Eicker, U.; Monien, D.; Duminil, É.; Nouvel, R. Energy performance assessment in urban planning competitions. Appl. Energy 2015, 155, 323-333. [CrossRef]

34. Chen, J.; Liu, J.; Liu, F. Empirical research on the green technological innovation auditing. Stud. Sci. Sci. 2002, 20, 107-112.

35. Severo, E.A.; Guimarães, J.C.F.; Dorion, E.C.H.; Nodari, C.H. Cleaner production, environmental sustainability and organizational performance: An empirical study in the Brazilian Metal-Mechanic industry. J. Clean. Product. 2015, 96, 118-125. [CrossRef]

36. Zhao, X.; Jiang, G.; Li, A.; Wang, L. Economic analysis of waste-to-energy industry in China. Waste Manag. 2016, 48, 604-618. [CrossRef] [PubMed]

37. Wang, J.; Zhao, T. Regional energy-environmental performance and investment strategy for China's non-ferrous metals industry: A non-radial dea based analysis. J. Clean. Prod. 2016, in press. [CrossRef]

38. Chen, J.; Chen, Y.; Vanhaverbeke, W. The influence of scope, depth, and orientation of external technology sources on the innovative performance of Chinese firms. Technovation 2011, 31, 362-373. [CrossRef]

39. Chen, J.; Dong, B. A nonparametric estimation on the effects of import and export trade to economic growth in China. Procedia Eng. 2012, 29, 952-956. [CrossRef]

40. Chen, G.; Yin, X.; Huang, L. Import trade, technology spillover and endogenous economic growth. Econ. Rev. 2008, 3, 34-40.

41. Huang, J.; Chen, X.; Huang, B.; Yang, X. Economic and environmental impacts of foreign direct investment in China: A spatial spillover analysis. China Econ. Rev. 2016. in press. [CrossRef]

42. $\mathrm{Xu}, \mathrm{H}$.; Deng, Y. Foreign direct investment lead to the pollution of the environment in China?-Spatial qualitative research based on china's provincial panel data. Manag. World 2012, 2, 30-43.

43. Wang, J.; Zhang, X. Hightech products import spillover, innovation ability and production efficiency. J. Quant. Tech. Econ. 2012, 9, 22-39.

44. Ramanathan, R. An Introduction to Data Envelopment Analysis: A Tool for Performance Measurement; SAGE Publications: New Delhi, India, 2003.

45. Aristovnik, A.; Seljak, J.; Mencinger, J. Performance measurement of police forces at the local level: A non-parametric mathematical programming approach. Expert Syst. Appl. 2014, 41, 1647-1653. [CrossRef]

46. Shuai, J.-J.; Wu, W.-W. Evaluating the influence of e-marketing on hotel performance by dea and grey entropy. Expert Syst. Appl. 2011, 38, 8763-8769. [CrossRef]

47. Wang, W.-K.; Lu, W.-M.; Liu, P.-Y. A fuzzy multi-objective two-stage dea model for evaluating the performance of US bank holding companies. Expert Syst. Appl. 2014, 41, 4290-4297. [CrossRef] 
48. Dong, Z.Q.; Zhang, Y.J. Accumulated social capital, institutional quality, and economic performance: Evidence from China. Econ. Syst. 2016, 40, 206-219. [CrossRef]

49. Ahmed, A.D.; Mmolainyane, K.K. Financial integration, capital market development and economic performance: Empirical evidence from Botswana. Econ. Model. 2014, 42, 1-14. [CrossRef]

50. Teixeira, A.A.C.; Queirós, A.S.S. Economic growth, human capital and structural change: A dynamic panel data analysis. Res. Policy 2016, 45, 1636-1648. [CrossRef]

51. Su, Y.Q.; Liu, Z.Q. The impact of foreign direct investment and human capital on economic growth: Evidence from Chinese cities. China Econ. Rev. 2016, 37, 97-109. [CrossRef]

52. Badinger, H. Output volatility and economic growth. Econ. Lett. 2010, 106, 15-18. [CrossRef]

53. Shao, B.B.M.; Lin, W.T. Assessing output performance of information technology service industries: Productivity, innovation and catch-up. Int. J. Prod. Econ. 2016, 172, 43-53. [CrossRef]

54. Bilgen, S. Structure and environmental impact of global energy consumption. Renew. Sustain. Energy Rev. 2014, 38, 890-902. [CrossRef]

55. Song, M.L.; Zheng, W.P.; Wang, Z.Y. Environmental efficiency and energy consumption of highway transportation systems in China. Int. J. Prod. Econ. 2015. in press. [CrossRef]

56. Rüdiger, D.; Schön, A.; Dobers, K. Managing greenhouse gas emissions from warehousing and transshipment with environmental performance indicators. Transp. Res. Procedia 2016, 14, 886-895. [CrossRef]

57. Heinonen, J.; Säynäjoki, A.; Junnonen, J.M.; Pöyry, A.; Junnila, S. Pre-use phase LCA of a multi-story residential building: Can greenhouse gas emissions be used as a more general environmental performance indicator? Build. Environ. 2016, 95, 116-125. [CrossRef]

58. Menikpura, S.N.M.; Sang-Arun, J.; Bengtsson, M. Assessment of environmental and economic performance of Waste-to-Energy facilities in Thai cities. Renew. Energy 2016, 86, 576-584. [CrossRef]

59. Noori, J.; Nasrabadi, M.B.; Yazdi, N.; Babakhan, A.R. Innovative performance of Iranian knowledge-based firms: Large firms or SMEs? Technol. Forecast. Soc. Chang. 2016. in press. [CrossRef]

60. Berchicci, L. Towards an open R\&D system: Internal R\&D investment, external knowledge acquisition and innovative performance. Res. Policy 2013, 42, 117-127.

61. Baumann, J.; Kritikos, A.S. The link between R\&D, innovation and productivity: Are micro firms different? Res. Policy 2016, 45, 1263-1274.

62. Li, X.Y.; Wang, J.; Liu, X.M. Can locally-recruited R\&D personnel significantly contribute to multinational subsidiary innovation in an emerging economy? Int. Bus. Rev. 2013, 22, 639-651.

63. Raymond, W.; Mairesse, J.; Mohnen, P.; Palm, F. Dynamic models of R\&D, innovation and productivity: Panel data evidence for Dutch and French manufacturing. Eur. Econ. Rev. 2015, 78, 285-306.

64. Driva, H.; Pawar, K.S.; Menon, U. Measuring product development performance in manufacturing organisations. Int. J. Prod. Econ. 2000, 63, 147-159. [CrossRef]

65. Koufteros, X.; Lu, G.; Peters, R.C.; Lai, K.H.; Wong, C.W.Y.; Cheng, T.C.E. Product development practices, manufacturing practices, and performance: A mediational perspective. Int. J. Prod. Econ. 2014, 156, 83-97. [CrossRef]

(C) 2016 by the authors; licensee MDPI, Basel, Switzerland. This article is an open access article distributed under the terms and conditions of the Creative Commons Attribution (CC-BY) license (http://creativecommons.org/licenses/by/4.0/). 